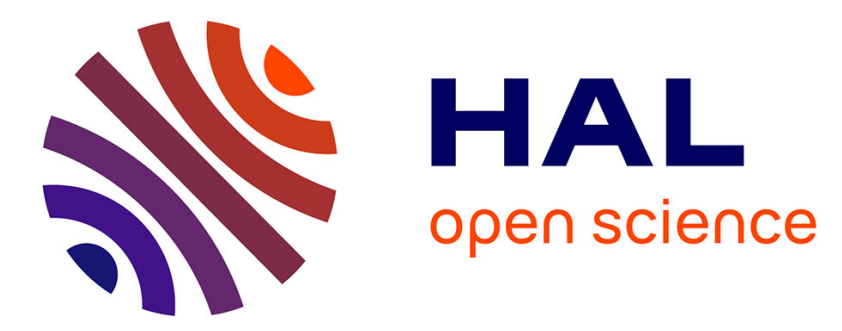

\title{
Carbonate counter pump stimulated by natural iron fertilization in the Polar Frontal Zone
}

Ian Salter, Ralf Schiebel, Patrizia Ziveri, Aurore Movellan, Richard Lampitt, George Wolff

\section{- To cite this version:}

Ian Salter, Ralf Schiebel, Patrizia Ziveri, Aurore Movellan, Richard Lampitt, et al.. Carbonate counter pump stimulated by natural iron fertilization in the Polar Frontal Zone. Nature Geoscience, 2014, 7 (12), pp.885-889. 10.1038/ngeo2285 . hal-03278278

\section{HAL Id: hal-03278278 \\ https://univ-angers.hal.science/hal-03278278}

Submitted on 5 Jul 2021

HAL is a multi-disciplinary open access archive for the deposit and dissemination of scientific research documents, whether they are published or not. The documents may come from teaching and research institutions in France or abroad, or from public or private research centers.
L'archive ouverte pluridisciplinaire HAL, est destinée au dépôt et à la diffusion de documents scientifiques de niveau recherche, publiés ou non, émanant des établissements d'enseignement et de recherche français ou étrangers, des laboratoires publics ou privés. 


\title{
Carbonate counter pump stimulated by natural iron fertilization in the Polar Frontal Zone
}

\author{
Ian Salter ${ }^{1,2 \star}$, Ralf Schiebel ${ }^{3}$, Patrizia Ziveri ${ }^{4,5}$, Aurore Movellan ${ }^{3}$, Richard Lampitt $^{6}$ \\ and George A. Wolff ${ }^{7}$
}

The production of organic carbon in the ocean's surface and its subsequent downward export transfers carbon dioxide to the deep ocean. This $\mathrm{CO}_{2}$ drawdown is countered by the biological precipitation of carbonate, followed by sinking of particulate inorganic carbon, which is a source of carbon dioxide to the surface ocean, and hence the atmosphere over 100-1,000 year timescales'. The net transfer of $\mathrm{CO}_{2}$ to the deep ocean is therefore dependent on the relative amount of organic and inorganic carbon in sinking particles ${ }^{2}$. In the Southern Ocean, iron fertilization has been shown to increase the export of organic carbon $^{3-5}$, but it is unclear to what degree this effect is compensated by the export of inorganic carbon. Here we assess the composition of sinking particles collected from sediment traps located in the Polar Frontal Zone of the Southern Ocean. We find that in high-nutrient, low-chlorophyll regions that are characterized by naturally high iron concentrations, fluxes of both organic and inorganic carbon are higher than in regions with no iron fertilization. However, the excess flux of inorganic carbon is greater than that of organic carbon. We estimate that the production and flux of carbonate in naturally iron-fertilized waters reduces the overall amount of $\mathrm{CO}_{2}$ transferred to the deep ocean by $6-32 \%$, compared to $1-4 \%$ at the non-fertilized site. We suggest that an increased export of organic carbon, stimulated by iron availability in the glacial sub-Antarctic oceans, may have been accompanied by a strengthened carbonate counter pump.

The biological carbon pump is the downward flux of particulate organic carbon (POC) from the surface to the deep ocean ${ }^{6}$. The fraction of settling POC that is not remineralized in the winter mixed layer sinks to depth, driving a reduction in surface ocean partial pressure of carbon dioxide $\left(\mathrm{pCO}_{2}\right)$ that is compensated by oceanic uptake of atmospheric $\mathrm{CO}_{2}$ (ref. 7). The iron hypothesis ${ }^{8}$ suggests that increased iron supply to the nutrient-rich, but irondeficient Southern Ocean, contributed towards the termination of glacial periods by enhancing phytoplankton growth and the biological carbon pump. Recent studies of natural systems ${ }^{3,4}$ and artificial $^{5}$ iron fertilization experiments support this idea by demonstrating enhanced POC flux well below the mixed layer into the deep ocean ${ }^{3-5}$.

Counteracting the organic carbon pump in terms of its influence on air-sea $\mathrm{CO}_{2}$ exchange is the carbonate counter pump ${ }^{9}$. The precipitation of $\mathrm{CaCO}_{3}$ shells by mainly coccolithophores, foraminifers (both calcite) and pteropods (aragonite), and the resulting particulate inorganic carbon (PIC) flux from the surface ocean, causes an increase in surface ocean $\mathrm{pCO}_{2}$ (ref. 10) on timescales of the order of 100-1,000 years ${ }^{1}$. As a result of these opposing effects, particle flux studies addressing deep-ocean $\mathrm{CO}_{2}$ sequestration need to discriminate between organic (soft-tissue) and inorganic carbon, with a strong focus on a relationship formalized as the rain ratio (POC:PIC; ref. 2). Despite its obvious importance for atmospheric $\mathrm{CO}_{2}$, the significance of $\mathrm{CaCO}_{3}$ export has not been explicitly considered in studies of iron fertilization in the Southern Ocean owing to observations that organic carbon fluxes are primarily mediated by non-calcifying phytoplankton ${ }^{4,5}$. However, foraminifers and pteropods are calcifying heterotrophs highly abundant in the Southern Ocean ${ }^{11,12}$ and may represent a dominant component of PIC flux to the deep ocean ${ }^{13}$.

We carried out measurements to characterize the dynamics of PIC export from a naturally iron-fertilized system in the Polar Frontal Zone (north of the Polar Front, south of the sub-Antarctic Front) and used these data to quantify the carbonate counter pump. Sediment trap samples were analysed from three deployment locations. Two of the traps, $[+\mathrm{Fe}] \mathrm{M} 10-\mathrm{N}$ and $[+\mathrm{Fe}] \mathrm{M} 5-\mathrm{NE}$, were deployed beneath an iron-enriched $[+\mathrm{Fe}]$ phytoplankton bloom area to the north and northeast of the Crozet Islands and the third, [HNLC]M6-S, in an iron-deficient high-nutrient low-chlorophyll (HNLC) zone to the south ${ }^{3}$ (Supplementary Information 1).

Our measurements quantitatively partition PIC fluxes amongst coccolith, pteropod and foraminifer fractions (Supplementary Information 2). We place particular emphasis on the species contributions of planktonic foraminifer because they are a dominant component of the $\mathrm{CaCO}_{3}$ fraction (Fig. 1a). Novel morphometric particle analyses were carried out with a fully automated incident light microscope to generate a continuous data set of test size. Manual classification and enumeration of particles were combined with empirically determined $\mathrm{CaCO}_{3}$ weights from the $[+\mathrm{Fe}]$ and HNLC regions to compute the contribution of individual species to total flux (Supplementary Methods).

At the iron fertilized sites we measured much larger annual fluxes of total, foraminifer-, coccolith- and pteropod-derived PIC to the deep ocean that were $7-10,6-8, \sim 9$ and $64-68$ times higher, respectively, than those in HNLC waters (Fig. 1a, Table 1 and Supplementary Information 3). Previous studies from the Crozet Islands indicate natural iron fertilization enhances

\footnotetext{
${ }^{1}$ Alfred Wegener Institute, Helmholtz Centre for Polar and Marine Research, Am Handelshafen 12, 27570 Bremerhaven, Germany. ${ }^{2}$ Sorbonne Universités, UPMC Univ Paris 06, CNRS UMR 7621, Laboratoire d'Océanographie Microbienne, Observatoire Océanologigique, F-66650 Banyuls/mer, France. ${ }^{3}$ Université d'Angers, UMR CNRS 6112, LPG-BIAF - Bio-Indicateurs Actuels et Fossiles, 2 Boulevard Lavoisier, Angers 49045, France. ${ }^{4}$ Universitat Autònoma de Barcelona, ICREA-ICTA, Edifici Z, Carrer de les columnes, E-08193 Bellaterra, Barcelona, Spain. ${ }^{5}$ Vrije Universiteit Amsterdam, Department of Earth Sciences, FALW, De Boelelaan 1105, 1081 HV Amsterdam, The Netherlands. ${ }^{6}$ National Oceanography Centre, Ocean Biogeochemistry and Ecosystems, Waterfront Campus, European Way, Southampton SO14 3ZH, UK. ${ }^{7}$ University of Liverpool, School of Environmental Sciences, 4 Brownlow Street, Liverpool L69 3GP, UK. *e-mail: ian.salter@awi.de
} 
a

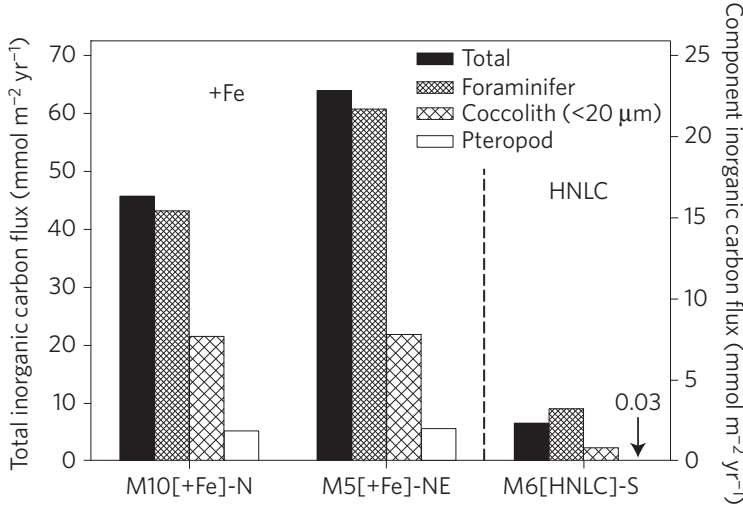

C

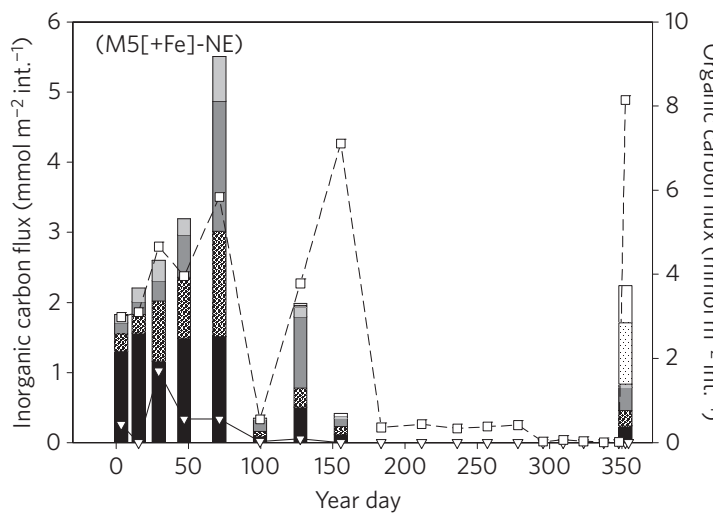

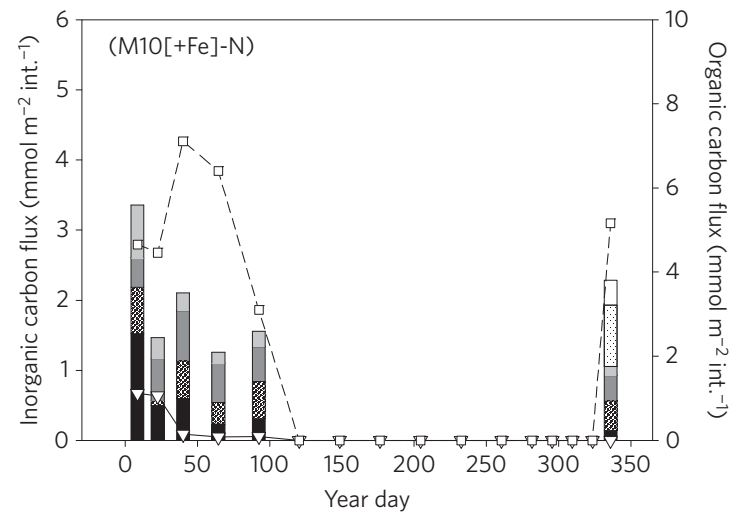

d

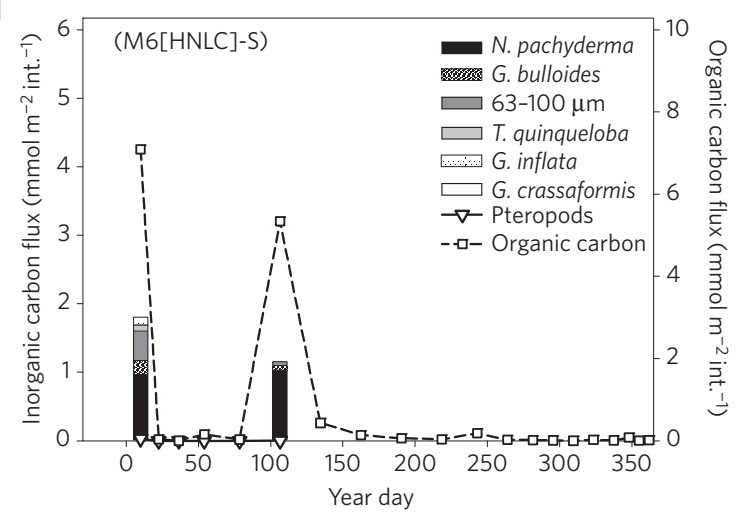

Figure 1 | Annual and seasonal inorganic carbon $\left(\mathrm{CaCO}_{3}\right)$ fluxes. a, Annual inorganic carbon fluxes of total, fine-fraction ( $\left.<20 \mu \mathrm{m}\right)$ coccolith, $>63 \mu \mathrm{m}$ foraminifer calcite and pteropod aragonite at M10[+Fe]-N (352 days), M5[+Fe]-NE (357 days) and M6[-Fe]-S (363 days) sediment trap deployment locations (Supplementary Information 1). b-d, Seasonality of inorganic carbon fluxes in the foraminifer and pteropod categories at the indicated traps. Time-series fluxes ( $\mathrm{mmol} \mathrm{m}{ }^{-2}$ int. $^{-1}$ ) are integrated over the sediment trap cup-sampling interval and centred on the interval midpoint (Supplementary Information 3). Absence of bars corresponds to periods of negligible mass flux. The sample cups in which foraminifer species analyses were conducted account for $99 \%$ of total annual $\mathrm{CaCO}_{3}$ fluxes (Supplementary Information 3).

new production, seasonally integrated shallow export, annually integrated deep-water POC flux, mega-faunal biomass and coretop organic carbon accumulation by a factor of two to three ${ }^{3,14}$. As a result of the disproportional response of PIC and POC fluxes to natural iron fertilization (Table 1) in the Polar Frontal Zone, deepocean rain ratios are reduced from 1.9 in HNLC waters to $0.6-0.8$ at the $[+\mathrm{Fe}]$ sites.

Annual carbon flux estimates from the iron-fertilized Crozet bloom were used to quantify the carbonate counter pump effect in reducing $\mathrm{CO}_{2}$ drawdown to the ocean interior. To achieve this we account for estimates of organic carbon flux at the base of the winter mixed layer (WML; $\sim 200 \mathrm{~m}$ at the Crozet study $\operatorname{site}^{15}$ ), deep-ocean PIC flux as a conservative estimate of WML $\mathrm{CaCO}_{3}$ production/export, and empirical determination of released $\mathrm{CO}_{2}$ : precipitated carbonate $(\Psi)$ (ref. 10) ratios. The principal calcifying organisms comprising the measured PIC flux in our study area (Fig. 1b-d) are known to live, and by extension calcify, in the upper $50-200 \mathrm{~m}$ of the water column ${ }^{11,12,16}$ - that is, above the ventilation depth-where they directly contribute to ocean-atmosphere $\mathrm{CO}_{2}$ equilibrium. Vertical profiles of dissolved inorganic carbon and total alkalinity were used to calculate regional values of $\Psi$ in the upper $200 \mathrm{~m}$ of $0.77 \pm 0.02(n=24)$ and $0.79 \pm 0.01(n=16)$ at the iron-fertilized and HNLC sediment trap deployment locations (Supplementary Information 4).

The resulting formulations are expressed as the reduction of $\mathrm{CO}_{2}$ drawdown at the base of the WML (Fig. 2a). Different estimates of WML POC export indicate that the carbonate counter pump effect ranges from $6-32 \%$ in the $[+\mathrm{Fe}]$ bloom region compared to $1-4 \%$ in the HNLC region. The $12-32 \%$ reductions derived from POC fluxes measured in deep-sediment traps are considered to be the most reliable estimates because POC and PIC flux budgets are integrated over comparable spatial and temporal scales. All the estimates are conservative because they do not correct for $\mathrm{CaCO}_{3}$ dissolution ${ }^{16,17}$ between the base of the WML and trap deployment depth (Supplementary Information 5). Consequently, we may have underestimated the significance of an iron-fertilized carbonate counter pump in the PFZ.

Although there is some variability in the magnitude of these estimates, they consistently demonstrate that iron fertilization promotes the role of the carbonate counter pump in mediating a reduction in deep-ocean $\mathrm{CO}_{2}$ storage. This reflects the fact that excess $([+\mathrm{Fe}]-[\mathrm{HNLC}])$ PIC fluxes resulting from iron fertilization are considerably larger than the corresponding excess organic carbon fluxes. This is true of $\mathrm{CaCO}_{3}$ production and flux for all calcifying plankton functional types (Fig. 1a and Table 1), although their relative distribution does not change significantly (Fig. 2b). Heterotrophic calcifiers, notably foraminifers, account for $34-49 \%$ of annual budgets and are thus the most important contributor to deep-ocean $\mathrm{CaCO}_{3}$ fluxes around the Crozet Plateau.

The seasonally integrated foraminifer test flux in $[+\mathrm{Fe}]$ waters is $0.8-1.3 \times 10^{-6}$ tests $\mathrm{m}^{-2}$; a six to ten times increase over HNLC fluxes (Supplementary Information 3). Iron supply modifies the occurrence and abundance of differently sized species (Fig. 1b-d). Although Neogloboquadrina pachyderma (mean size 
a

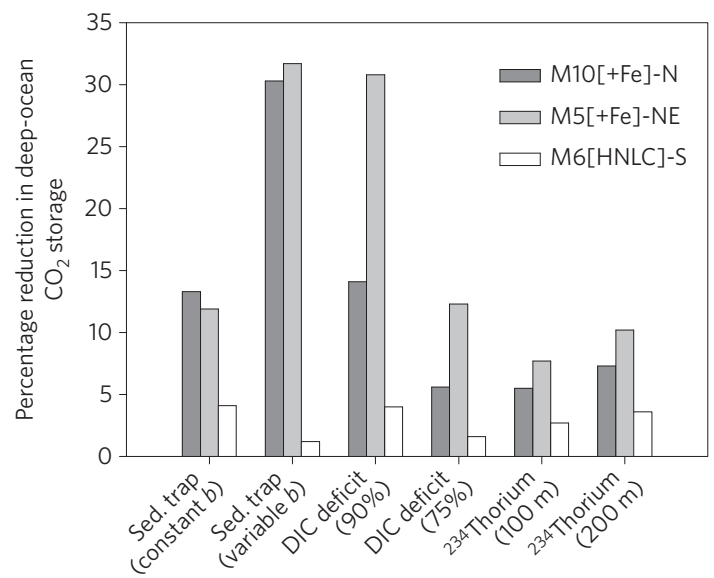

b

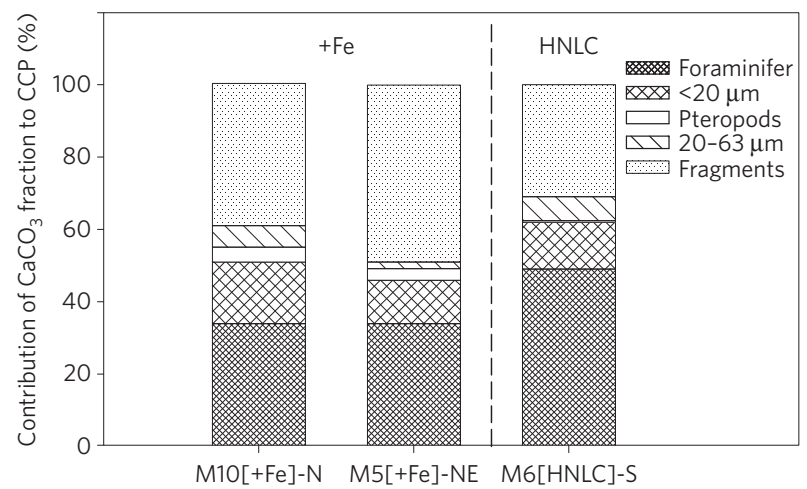

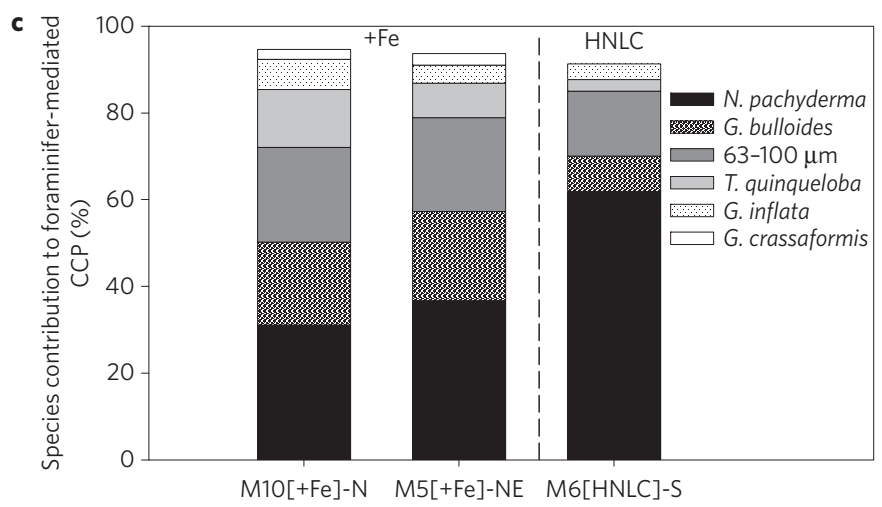

Figure 2 | Impact of the carbonate counter pump (CCP) and the contribution of $\mathrm{CaCO}_{3}$ fractions and foraminifer species in reducing deep-ocean $\mathrm{CO}_{2}$ storage. $\mathbf{a}$, The reduction in deep-ocean $\mathrm{CO}_{2}$ storage calculated from different methodological estimates of POC export beyond the ventilation depth. Sediment trap (Sed. Trap) estimates are annual deep-ocean POC fluxes extrapolated to winter mixed layer using either a constant or bloom/HNLC-variable POC attenuation coefficient (Methods). Dissolved inorganic carbon estimates are based on seasonal drawdown ${ }^{29}$ and mixed layer remineralization rates of $90 \%$ or $75 \%$ (Supplementary Information 4). ${ }^{234}$ Th estimates are based on seasonal estimates extrapolated to 150 and $200 \mathrm{~m}$ (ref. 3). b,c, Relative contribution of $\mathrm{CaCO}_{3}$ fractions (b) and foraminifer species within the foraminifer fraction (c) to the CCP. In $\mathbf{b}$, fragments is the residual between calculated and measured $\mathrm{CaCO}_{3}$ (See Supplementary Methods). In c, the 63-100 $\mu \mathrm{m}$ fraction refers to small, mainly juvenile, foraminifer that could not be classified. Foraminifer aggregates and fragments (Supplementary Methods) are not included; they account for 5-9\% of foraminifer- $\mathrm{CaCO}_{3}(\mathrm{Supplementary}$ Information 3).

Table 1 | Excess fluxes resulting from iron fertilization.

\begin{tabular}{llllll} 
& $\mathbf{C}_{\text {org }}$ & $\mathrm{C}_{\text {inorg }}$ & $\mathrm{C}_{\text {inorg }}$ & $\mathrm{C}_{\text {inorg }}$ & $\mathrm{C}_{\text {inorg }}$ \\
& Total & Total & Foraminifer & Pteropod & $<\mathbf{2 0} \boldsymbol{\mu m}$ \\
\hline Excess fluxes* $^{*}$ & $24-27$ & $39-57$ & $13-19$ & $1.9-2.0$ & $6.9-7.0$ \\
Increase $^{\dagger}$ & $\sim 3$ & $7-10$ & $6-8$ & $64-68$ & $\sim 9$
\end{tabular}

*Excess fluxes in $\mathrm{mmol} \mathrm{m}^{-2} \mathrm{yr}^{-1}$ calculated as $[+\mathrm{Fe}]-[\mathrm{HNLC}]$ annual fluxes. ${ }^{\dagger}$ Factor increase, calculated as $[+\mathrm{Fe}] /[\mathrm{HNLC}]$.

\pm 1 s.d. $=166 \pm 32 \mu \mathrm{m})$ is the dominant foraminifer species at all sites, its relative abundance decreases from 62 to $34 \pm 4 \%$ as a result of iron fertilization (Fig. 2c). There are corresponding increases in the larger species Globigerina bulloides $(247 \pm 62 \mu \mathrm{m})$, Globorotalia inflata $(337 \pm 93 \mu \mathrm{m})$ and Globorotalia crassaformis $(353 \pm 82 \mu \mathrm{m})$ in addition to Turborotalita quinqueloba $(172 \pm 30 \mu \mathrm{m})$. G. inflata and G. crassaformis were less common and occurred primarily in association with initial export events in December and January (Fig. 1b-d). Their large size, representing mostly adult specimens, resulted in contributions reaching $52-59 \%$ of overall foraminifer-PIC fluxes at those specific times, although their overall contribution to annual fluxes was $<10 \%$. The fluxes of $G$. bulloides and T. quinqueloba were sustained throughout the entire export season and their contributions to annual foraminifer- $\mathrm{CaCO}_{3}$ budgets were approximately double under iron supply-that is, $20 \pm 1.0 \%$ versus $9 \%$ and $11 \pm 3.9 \%$ versus $2.7 \%$, respectively.

The continuous data set enabled us to compare assemblage size and calcification intensity (size-normalized weights; SNW; ref. 18) of each foraminifer species (Supplementary Methods). Statistically significant differences in assemblage size and SNWs were not observed in relation to regional differences in iron supply (Supplementary Information 6). However, ranges of a factor of two in SNWs were observed for G. bulloides $(\sim 5-10 \mu \mathrm{g})$ and $N$. pachyderma $(\sim 2-4 \mu \mathrm{g})$ in both $[+\mathrm{Fe}]$ and HNLC waters at different times of year (Supplementary Information 6) and are possibly related to temporal dynamics in food supply, calcification depths and $\mathrm{CO}_{2}$ concentrations ${ }^{18}$. Therefore, assemblage shifts towards species that have higher calcite mass per individual combine with increases in test abundance (Fig. 1) to enhance foraminifer$\mathrm{CaCO}_{3}$ fluxes and drive the observed patterns of species-specific contributions to the carbonate counter pump (Fig. 2c).

The geographical location of the iron-fertilized Crozet bloom is of some significance concerning the role of iron in promoting carbonate counter pump effects. The northernmost extent of the bloom is demarcated by the sub-Antarctic Front (Supplementary Information 1); a boundary that marks a known geochemical transition towards carbonate-dominated export $\mathrm{t}^{19,20}$ (Supplementary Information 7). Previous studies examining temperature and salinity profiles indicate the limited cross frontal 
a

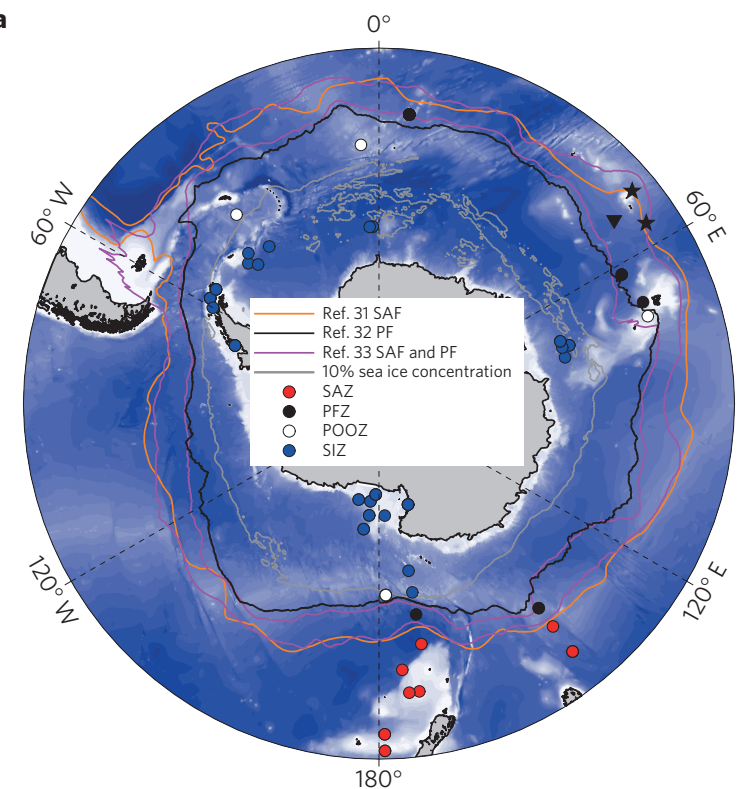

b

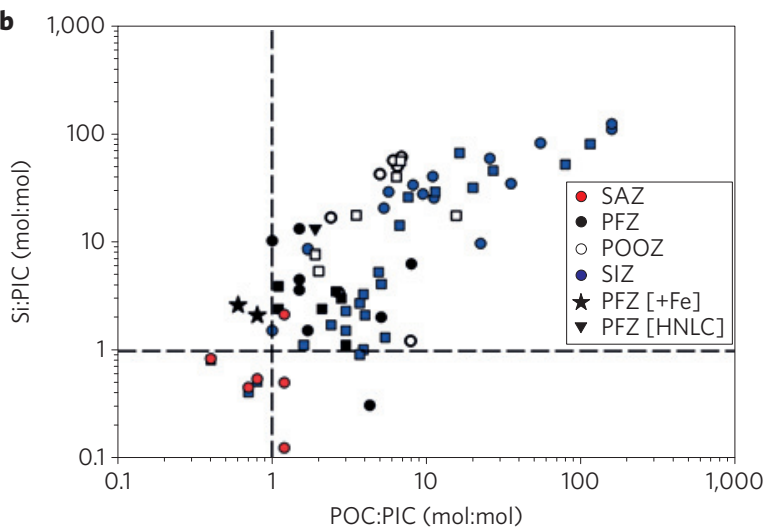

Figure 3 | Comparison of particulate geochemical signatures comprising Southern Ocean flux. a, Map showing sediment trap deployment locations (Supplementary Fig. 8) in relation to Southern Ocean fronts and sea-ice extent (Supplementary Methods). SAF-sub-Antarctic Front, PF-Polar Front, SAZ-sub-Antarctic Zone, PFZ-Polar Frontal Zone,

POOZ-permanently open ocean zone, SIZ-seasonal ice zone (b) POC:PIC ratios of annual flux compared to Si:PIC ratios. Squares denote sediment traps deployed shallower than $1,000 \mathrm{~m}$. Dashed lines mark unity. PFZ[+Fe] and PFZ[HNLC $]$ correspond to the M10 $[+\mathrm{Fe}]-\mathrm{N}, \mathrm{M} 5[+\mathrm{Fe}]-\mathrm{NE}$ and M6[HNLC]-S sediment trap fluxes around the Crozet Plateau (this study).

exchange and influence of SAZ waters within the Crozet bloom area $^{15}$. In support of this finding, opal is the dominant biogenic sedimentary component around the plateau ${ }^{21}$. To further validate our inferences regarding an iron-fertilized carbonate counter pump, we analysed the geochemical signatures of all published estimates of annual export in the Southern Ocean (Fig. 3 and Supplementary Information 8). The POC:PIC ratio from HNLC waters south of Crozet is comparable to other measurements in the same frontal region. However, the combined geochemical signature of Si:PIC ratios $>1$ (diatom-dominated production/export) and POC:PIC ratios $<1$ measured from the Crozet bloom is a feature uniquely consistent with the scenario of PFZ iron fertilization. Strengthening of the carbonate counter pump north of the Crozet Plateau occurs primarily due to enhancement of $\mathrm{CaCO}_{3}$ production and flux in response to iron fertilization, rather than a shift from silicate-dominated production characteristic north of the sub-Antarctic Front ${ }^{19,20}$.
Although characteristic of the PFZ in general, the Si:PIC ratios in the HNLC area $[11 \pm 2.2(n=3)]$ are significantly higher $(P<0.005$; two-tailed $t$-test $)$ than those in the $[+\mathrm{Fe}]$ regime $[2.6 \pm 0.6(n=3)]$ (Fig. 3b and Supplementary Methods). The ironlimited PFZ is characterized by the production of large, heavily silicified diatom species resistant to grazing, and the resulting flux of their empty frustules ${ }^{4}$. Consequently, despite enhanced phytoplankton production in response to natural iron supply north of the Crozet Plateau ${ }^{3}$, biogenic $\mathrm{SiO}_{2}$ fluxes to the deep ocean are similar in both $[+\mathrm{Fe}]$ and HNLC environments ${ }^{4}$. The observable decrease in deep-ocean POC:PIC ratios resulting from iron fertilization in the PFZ is therefore attributable to an increase in PIC fluxes relative to both $\mathrm{POC}$ and $\mathrm{SiO}_{2}$.

Changes in Southern Ocean organic carbon export resulting from iron fertilization have been evoked to explain $\sim 40 \mathrm{ppm}$ of the $\mathrm{CO}_{2}$ decline occurring over the Last Glacial Maximum ${ }^{22,23}$. Sedimentary records provide evidence that increases in nutrient utilization and export occurred in the sub-Antarctic portion of the Southern Ocean ${ }^{24,25}$ and have been linked to alteration of aeolian iron supply ${ }^{26,27}$. Our data suggests that under a scenario of glacial iron fertilization, strengthening of the carbonate counter pump in the sub-Antarctic may have accompanied any increases in organic carbon export. The planktonic foraminifer assemblages in our samples are typical species of sediments underlying the subAntarctic Front (SAF) to Antarctic Polar Front (APF) during the late Pleistocene and Holocene ${ }^{28}$, and may have affected deep-ocean rain ratios in the manner proposed here. Understanding the response of inorganic carbon flux to iron supply in this region is therefore necessary to fully elucidate the role of the biological carbon pump in glacial $\mathrm{CO}_{2}$ drawdown. The dominant but variable response of foraminifer species to iron-fertilized production provides a strong rationale for quantifying $\mathrm{CaCO}_{3}$ fluxes at the species level. It is only with such detailed approaches that we can hope to advance our understanding of the complex interactions between ocean biota and climate.

\section{Methods}

Sediment traps. Traps were McLane 21-cup time-series arrays deployed on bottom-tethered moorings ${ }^{4}$. The traps all functioned well in the water column (Supplementary Information). Although unusual, the punctuated flux pattern at [HNLC]M6-S was identical to two additional annual flux profiles south of the plateau (Supplementary Methods)

Foraminifer and pteropod $\mathrm{CaCO}_{3}$. Samples were dry split according to the number of particles present (1/1-1/32, but generally $1 / 8$ splits); with the exception of larger particles $(>400 \mu \mathrm{m})$, which were removed and weighed separately to avoid splitting uncertainty. Particle analyses were carried out with a fully automated incident light microscope system. Particles were manually classified and counted from the digital images and verified directly from the samples if necessary. Planktonic foraminifer test calcite mass is determined for each sampling interval of each sediment trap-and for each species and test size fraction. Pteropods of the three species Limacina inflata, Limacina retroversa, and Limacina helicina were counted from the 63 to $100 \mu \mathrm{m}$ and $>100-\mu \mathrm{m}$ size fractions or referred to as pteropod fragments if no classification was possible. Whole pteropod shells and fragments from the $>100-\mu \mathrm{m}$ size fraction were weighed with a microbalance to directly determine their $\mathrm{CaCO}_{3}$ (aragonite) mass. To determine the aragonite weight of pteropods $>400 \mu \mathrm{m}$, the entire assemblage was weighed-that is, all species and fragments together (Supplementary Methods).

Total and fine-fraction $\mathrm{CaCO}_{3}$. Total particulate $\mathrm{CaCO}_{3}$ was determined on freeze-dried sediments using a Carlo-Erba NA-1500 elemental analyser. Inorganic carbon was determined following the removal of organic carbon by direct acidification and converted to $\mathrm{CaCO}_{3}$. Coccolith- $\mathrm{CaCO}_{3}$ fluxes were estimated from the determination of fine-fraction carbonate weights in the $<63 \mu \mathrm{m}$ and $20-63 \mu \mathrm{m}$ fractions. A $1 / 80$ aliquot was wet-sieved over a $20 \mu \mathrm{m}$ mesh and the two size fractions filtered on 0.4 polycarbonate membranes. The filters and particulate material were leached in $10 \mathrm{ml} 1 \% \mathrm{HNO}_{3}$ solution and the calcium content of the samples determined by inductively coupled plasma atomic emission spectroscopy (ICP-AES). Further details can be found in Supplementary Methods. 
Carbon drawdown reduction. The percentage reduction in molar carbon dioxide drawdown by the carbonate counter pump is calculated as: $\left\{\left[\left(\right.\right.\right.$ gross $\mathrm{CO}_{2}$ sink) - (net $\mathrm{CO}_{2}$ sink) $] /\left(\right.$ gross $\mathrm{CO}_{2}$ sink $\left.)\right\} \times 100$ (see Supplementary Information 4). Gross $\mathrm{CO}_{2}$ sink $=\mathrm{FPOC}_{\mathrm{WML}}$ and the net $\mathrm{CO}_{2}$ sink $=\left[\left(\mathrm{FPOC}_{\mathrm{WML}}\right)-\left(\mathrm{FPIC}_{\mathrm{WML}} \times \Psi\right)\right]$, where FPOC $_{\mathrm{WML}}$ and FPIC $_{\mathrm{WML}}$ are the export fluxes of particulate organic carbon and particulate inorganic carbon, respectively, at the base of the winter mixed layer $(200 \mathrm{~m}$; ref. 15$)$ and $\Psi$ is the released $\mathrm{CO}_{2}$ :precipitated carbonate ratio ${ }^{10}$. The $\mathrm{CaCO}_{3}$ fluxes measured at the sediment trap deployment depths of 2,000-3,195 m were taken as a minimum estimate of $\mathrm{CaCO}_{3}$ fluxes at the base of the winter mixed layer and converted into molar inorganic carbon fluxes (FPIC). $\Psi$ values were determined based on the mixed layer inventories of dissolved inorganic carbon and total alkalinity at the sediment trap deployment locations ${ }^{29}$ (see Supplementary Information 4). Particulate organic carbon (POC) fluxes measured at the sediment trap deployment depth were normalized to the base of the winter mixed layer $(200 \mathrm{~m})$ using the expression: $F_{\mathrm{WML}}=F_{d}(\mathrm{WML} / d)^{-b}$, where $F_{d}$ is the flux at the sediment trap deployment depth, $d$ is the sediment trap deployment depth, WML is $200 \mathrm{~m}$ and the exponent $b$ characterizes the attenuation of flux with depth. Under the constant remineralization scenario a $b$ value of 0.85 was used for all three sites and for the regionally variable scenario a $b$ value of 0.5 (ref. 30) was used at $\mathrm{M} 10[+\mathrm{Fe}]-\mathrm{N}$ and M5[+Fe]-NE and a $b$ value of 1.3 (ref. 30) at M6[HNLC]-S Estimates based on DIC deficits were calculated from seasonal DIC drawdown at the different sediment trap deployment locations ${ }^{29}$ (M10-N, M5-NE, M6-S) and assuming $90 \%$ and $75 \%$ of sinking POM is remineralized in the upper $200 \mathrm{~m}$. POC export derived from uranium to thorium disequilibria at $100 \mathrm{~m}$ were scaled to seasonal export values using a Si biogeochemical budget ${ }^{3}$. The values were extrapolated to $150 \mathrm{~m}$ and $200 \mathrm{~m}$ with a Martin-type exponent fitted to the deep-sediment trap fluxes ${ }^{3}$.

Received 28 May 2014; accepted 6 October 2014; published online 10 November 2014

\section{References}

1. Zeebe, R. E. History of seawater carbonate chemistry, atmospheric $\mathrm{CO}_{2}$, and ocean acidification. Annu. Rev. Earth Planet. Sci. 40, 141-165 (2012).

2. Antia, A. N. et al. Basin-wide particulate carbon flux in the Atlantic Ocean: Regional export patterns and potential for atmospheric $\mathrm{CO}_{2}$ sequestration. Glob. Biogeochem. Cycles 15, 845-862 (2001).

3. Pollard, R. T. et al. Southern Ocean deep-water carbon export enhanced by natural iron fertilization. Nature 457, 577-580 (2009).

4. Salter, I. et al. Diatom resting spore ecology drives enhanced carbon export from a naturally iron-fertilized bloom in the Southern Ocean. Glob. Biogeochem. Cycles 26, GB1014 (2012).

5. Smetacek, V. et al. Deep carbon export from a Southern Ocean iron-fertilized diatom bloom. Nature 487, 313-319 (2012).

6. Volk, T. \& Hoffert, M. I. in The Carbon Cycle and Atmospheric $\mathrm{CO}_{2}$ : Natural Variations Arcana to Present Vol. 32 (eds Sunquist, E. T. \& Broeker, W. S.) 99-111 (Geophys. Monogr. Series, American Geophysical Union, 1985).

7. Sigman, D. M. \& Boyle, E. A. Glacial/interglacial variations in atmospheric carbon dioxide. Nature 407, 859-869 (2000).

8. Martin, J. H. Glacial-interglacial $\mathrm{CO}_{2}$ change: The iron hypothesis. Paleoceanography 5, 1-13 (1990).

9. Heinze, C., Maier-Reimer, E. \& Winn, K. Glacial $\mathrm{pCO}_{2}$ reduction by the world ocean: Experiments with the Hamburg carbon cycle model. Paleoceanography 6, 395-430 (1991).

10. Frankingnoulle, M., Canon, C. \& Gattuso, J. P. Marine calcification as a source of carbon dioxide: Positive feedback of increasing atmospheric $\mathrm{CO}_{2}$. Limnol. Oceanogr. 39, 458-462 (1994).

11. King, A. L. \& Howard, W. R. $\partial^{18} \mathrm{O}$ seasonality of planktonic foraminifera from Southern Ocean sediment traps: Latitudinal gradients and implications for paleoclimate reconstructions. Mar. Micropaleontol. 56, 1-24 (2005).

12. Howard, W. R. et al. Distribution, abundance and seasonal flux of pteropods in the Sub-Antarctic Zone. Deep-Sea Res. II 58, 2293-2300 (2011).

13. Schiebel, R. Planktic foraminiferal sedimentation and the marine calcite budget. Glob. Biogeochem. Cycles 16, 1065 (2002).

14. Wolff, G. A. et al. The effects of natural iron fertilization on deep sea ecology: The Crozet Plateau, Southern Indian Ocean. PLoS ONE 6, e20697 (2011).

15. Venables, H. J., Pollard, R. T. \& Popova, E. E. Physical conditions controlling the development of a regular phytoplankton bloom north of the Crozet Plateau, Southern Ocean. Deep-Sea Res. II 54, 1949-1965 (2007).
16. Roberts, D. et al. Interannual pteropod variability in sediment traps deployed above and below the aragonite saturation horizon in the Sub-Antarctic Southern Ocean. Polar Biol. 34, 1739-1750 (2011).

17. Schiebel, R. et al. Planktic foraminiferal dissolution in the twilight zone. Deep-Sea Res. II 54, 676-686 (2007).

18. Moy, A. D. et al. Reduced calcification in modern Southern Ocean planktonic foraminifera. Nature Geosci. 2, 276-280 (2009).

19. Honjo, S. et al. Particle fluxes to the interior of the Southern Ocean in the Western Pacific sector along $170^{\circ}$ W. Deep-Sea Res. II 47, 3521-3548 (2000).

20. Trull, T. et al. Moored sediment trap measurements of carbon export in the Subantarctic and Polar Frontal Zones of the Southern Ocean, south of Australia. J. Geophys. Res. 106, 31489-31509 (2001).

21. Marsh, R. et al. Controls on sediment geochemistry in the Crozet region. Deep-Sea Res. II 54, 2260-2274 (2007).

22. Watson, A. J. et al. Effect of iron supply on Southern Ocean $\mathrm{CO}_{2}$ uptake and implications for atmospheric $\mathrm{CO}_{2}$. Nature 407, 730-733 (2000).

23. Sigman, D. M. et al. The polar ocean and glacial cycles in atmospheric $\mathrm{CO}_{2}$ concentration. Nature 466, 47-55 (2010).

24. Robinson, R. S. et al. Diatom-bound ${ }^{15} \mathrm{~N} /{ }^{14} \mathrm{~N}$ : New support for enhanced nutrient consumption in the ice age subantarctic. Paleoceanography 20, PA3003 (2005).

25. Kohfeld, K. E. et al. Role of marine biology in glacial-interglacial $\mathrm{CO}_{2}$ cycles. Science 308, 74-78 (2005)

26. Mahowald, N. M. et al. Change in atmospheric mineral aerosols in response to climate: Last glacial period, preindustrial, modern and doubled carbon dioxide climates. J. Geophys. Res. 111, D10202 (2006)

27. Martínez-Garcia, A. et al. Iron fertilization of the Subantarctic Ocean during the last ice age. Science 343, 1347-1350 (2014).

28. Bé, A. W. H. \& Hutson, W. H. Ecology of planktonic foraminifer and biogeographic patterns of life and fossil assemblages in the Indian Ocean. Micropaleontology 23, 369-414 (1977).

29. Bakker, D. C. et al. The island mass effect and biological carbon uptake for the subantarctic Crozet Archipelago. Deep-Sea Res. II 54, 2174-2190 (2007)

30. Buesseler, K. O. et al. Revisiting carbon flux through the ocean's twilight zone. Science 316, 567-570 (2005).

31. Orsi, A. H. et al. On the meridional extent and fronts of the Antarctic Circumpolar Current. Deep-Sea Res. I 42, 641-673 (1995).

32. Moore, J. K. et al. Location and dynamics of the Antarctic polar front from satellite sea surface temperature data. J. Geophys. Res. 104, 3059-3073 (1999).

33. Sallée, J. B. et al. Southern Ocean fronts and their variability to climate modes. J. Clim. 12, 3020-3039 (2008).

\section{Acknowledgements}

Sediment trap deployments were funded through the NERC programmes CROZeX (PI: Pollard, R.T) and Benthic Crozet (PI: Wolff, G.A.). P.Z. was funded through the projects CGL2009-10806 (MinECo) and 265103 (EC-FP7). We are grateful to the captain and crew of R.R.S. Discovery for their support throughout the cruises D285, D286 and D300. We thank D. Bakker for sharing published DIC and TA data, calculating omega values and her detailed comments. M. Rembauville assisted in the preparation of Fig. 3. We are also grateful to M. C. Nielsdóttir and S. Blain for commenting on earlier versions of the manuscript. Finally we acknowledge the scientific participants of the CROZeX and Benthic Crozet programmes.

\section{Author contributions}

I.S. formulated the idea and together with R.S. designed the analytical approach. I.S. wrote the manuscript with all co-authors commenting. I.S. and R.S. performed all preparation and classification measurements on the foraminifer and pteropod fractions. A.M. measured calcite and aragonite mass of individual tests and R.S. and I.S. synthesized data. P.Z. performed ICP-AES measurements on the fine fraction. I.S. performed all bulk chemical analyses. G.W. and R.L. provided access to the sediment trap samples collected during the Benthic Crozet and CROZeX research programmes, respectively. All co-authors contributed to the manuscript.

\section{Additional information}

Supplementary information is available in the online version of the paper. Reprints and permissions information is available online at www.nature.com/reprints. Correspondence and requests for materials should be addressed to I.S.

\section{Competing financial interests}

The authors declare no competing financial interests. 